\title{
Perbedaan Efektivitas Metode Terapi Musik Religi Dengan Massage Effleurage Terhadap Nyeri Persalinan Kala I Fase Aktif Primigravida
}

\author{
Sri Wulan, Novita Br Ginting Munthe ${ }^{2}$ \\ Institut Kesehatan Medistra Lubuk Pakam \\ Jl. Sudirman No 38 Lubuk Pakam Kab.Deli Serdang, Sumatera Utara. \\ e-mail : wulan194@gmail.com
}

DOI : https://doi.org/10.35451/jkk.v2i1.302

\begin{abstract}
Pain is an unpleasant condition that is part of childbirth caused by physical or emotional stimulation. Labor pain management is needed to break the pain loop with all the consequences caused. Treatment of non-pharmacological pain is more selected because it is cheaper, safer, and can be done by maternity mothers or families such as religious music therapy and Effleurage Massage. This research aims to determine the difference in effectiveness of religious music therapy method with Massage Effleurage against maternity pain when I active phase Primigravida. This research was a Quasi-experiment with Pre and Post Test With Non Control Design, comparing two observations, namely Pre and Post Test of religious music therapy Group and Massage Effleurage Group. The instrument used was the Numeric Rating scale (NRS) scale observation sheet 0 10. The population in this study was a normal maternity mother who was in RS GrandMed Lubuk Pakam. The Sample used Probability Sampling technique with a sample amount of 36 people. The results of data analysis by using Independent $T$ Test test showed the value of $P$ value $0.02<0.05$ which means there was a significant distinction between giving methods of religious music therapy with massage effleurage. Recommended to maternity mothers in order to apply the therapy for religious music and massage effleurage because both methods were effectively used to reduce labor pains.
\end{abstract}

Kata Kunci : Religious Music Therapy, Massage Effleurage, labor pain.

\section{PENDAhuluan}

Menurut World Health Organization (WHO) kematian ibu hamil, bersalin dan nifas dapat disebabkan secara langsung ataupun tidak langsung, pada setiap tahun lebih dari 200 juta ibu hamil berakhir dengan persalinan bayi hidup dan ibu yang sehat, walaupun demikian banyak kasus persalinan bukanlah hal yang membahagiakan tetapi menjadi suatu keadaan yang penuh dengan persaaan takut, dan rasa nyeri saat persalinan (Yuliatun., L. 2010).Dampak dari nyeri pada saat persalinan dapat menimbulkan gangguan psikologis pada ibu, yang mengakibatkan timbulnya hiperventilasi sehingga kebutuhan oksigen dan tekanan darah dalam tubuh ibu menjadi lebih 
meningkat. Keadaan ini dapat merangsang peningkatan katekolamin yang berlebihan seperti ephinephrine dan norephinephrine beda (Wulan., S., \& Gurusinga., R. 2018).

Tingkat kotekolamin yang tinggi dalam darah dapat menyebabkan gangguan pada kontraksi uterus sehingga mengakibatkan persalinan menjadi lama serta dapat mengurangi aliran darah menuju plasenta. Keadaan ini dapat mengakibatkan trauma pada bayi serta dapat menyebabkan kematian pada ibu dan bayi (Utomo., Armiyati., \& Arif. 2015). Dari hasil survei awal yang dilakukan oleh peneliti pada tanggal 01 Mei 2018 di RS GrandMed Lubuk Pakam ibu yang melahirkan secara normal pada bulan November 2017 - April 2018 sebanyak 67 orang, jumlah ibu primigravida sebanyak 39 orang. Saat itu dijumpai 3 pasien bersalin 1 diantaranya adalah primigravida. Ibu tersebut mengatakan tidak tahan dengan nyeri yang dirasakanya, nyeri terasa di bagian perut, atas simpisis. Ibu terus merasakan nyeri bahkan meminta untuk di operasi sectio caesarea.

Penanganan dan pemantauan nyeri pada saat proses persalinan terutama pada ibu bersalin primigravida sangat penting, karena merupakan tolak ukur apakah ibu bersalin dapat melewati proses persalinan normal atau berakhir dengan operasi secsio caesarea karena penyulit yang ditimbulkan oleh rasa nyeri yang sangat berat (M., Judha., Sudarti \& A., Fauziah. 2012) Tidak mudah untuk dapat menghilangkan perasaan takut yang sudah berakar, akan tetapi bidan dapat melakukan banyak hal salah satunya adalah dengan melakukan tindakan nonfarmakologi seperti terapi musik religi dan Massage Effleurage (Maryunani., A. 2010).

Terapi musik religi dapat mendekatkan ibu bersalin terhadap Tuhan Yang Maha Esa selain itu musik terapi juga dapat memperlambat dan menyeimbangkan gelombang otak serta dapat menstimulus pengeluaran pada hormon endofrin sehingga ibu dapat lebih tenang dalam menjalani proses persalinan (Wulandari., P., \& Nur., Hiba., D. 2015). Sedangkan Massage Efflaurage dapat menghasilkan implus yang dikirim melalui serabut saraf otak besar yang berada pada permukaan kulit, serabut ini dapat menghambat rasa nyeri sehingga otak tidak dapat menerima rangsangan nyeri karena sudah diblokir oleh stimulus kulit tersebut (Wulan., S., Soejoenoes, A., M, S., Hidayat, S., Widyawati., M., \& Gurusinga, R. 2017).

Penelitian ini dilakukan untuk menganalisa "Perbedaan Efektivitas Metode Terapi Musik Religi Dengan Massage Effleurage Terhadap Nyeri Persalinan Kala I fase aktif pada Primigravida di Rumah Sakit Grandmed Lubuk Pakam".

\section{METODE}

Jenis penelitian ini merupakan penelitian kuantitatif, dengan Desain QuasiEksperiment (Eksperiment Semu) dengan rancangan Pre and Post Test With Non Control Design yaitu suatu desain penelitian yang bertujuan menguji hubungan sebab akibat. Populasi pada penelitian ini adalah Seluruh Ibu Bersalin Normal yang berada di RS GrandMed Lubuk Pakam Kabupaten Deli Serdang. Penelitian dilaksanakan mulai Mei - Agustus 2019.

Pengambilan sampel dengan menggunakan tehnik Probability Sampling dengan menentukan kriteria inklusi dan eksklusi sebanyak 36 orang ibu bersalin normal yang akan di bagi menjadi dua kelompok yaitu 18 orang untuk kelompok Terapi Musik Religi dan 18 orang untuk kelompok Massage Effleurage (Dahlan., S., M. 2013).

Data primer dalam penelitian ini diperoleh melalui observasi langsung terhadap skala nyeri pada ibu bersalin normal. Data sekunder dalam penelitian ini diperoleh dari rekam medik atau cacatan dari RS GrandMed Lubuk Pakam. Instrument yang digunakan pada penelitian ini adalah Numerical Rating Scal (NRS) 0-10. 
Analisa data yang digunakan pada penelitian ini adalah analisa Univariat untuk mengetahui sebelum dan sesudah intervensi dengan menggunakan Uji Paired T-Test, Analisa Bivariat untuk melihat perbedaan Efektivitas Terapi Musik Religi dengan Massage Effleurage, mengunakan Uji Independent T Test, dengan Taraf signifikan $95 \%(a=0.05)$ (Hastono., P., S. 2011).

\section{HASIL}

a. Hasil Analisis Sebelum (Pretest) Dan Sesudah (Posttest) Pada Kelompok Terapi Musik Religi

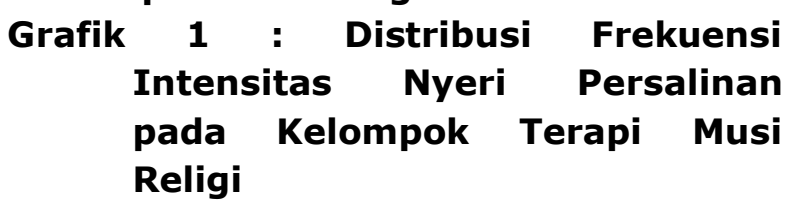

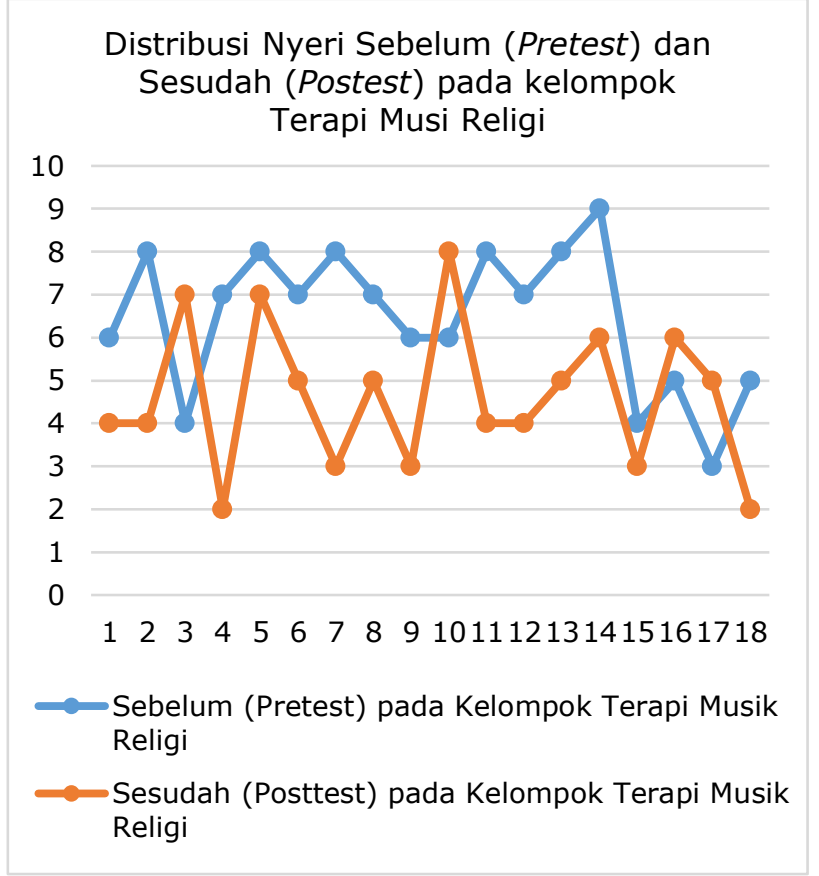

Tabel 1. Perbedaan nyeri persalinan pada kelompok terapi musik religi (sebelum) pretest dan (sesudah) posttest intervensi.

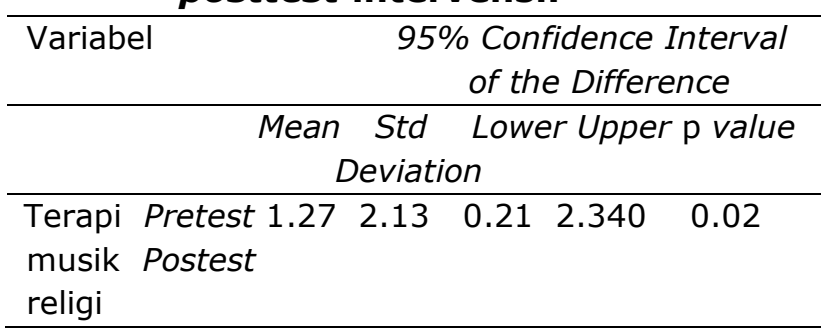

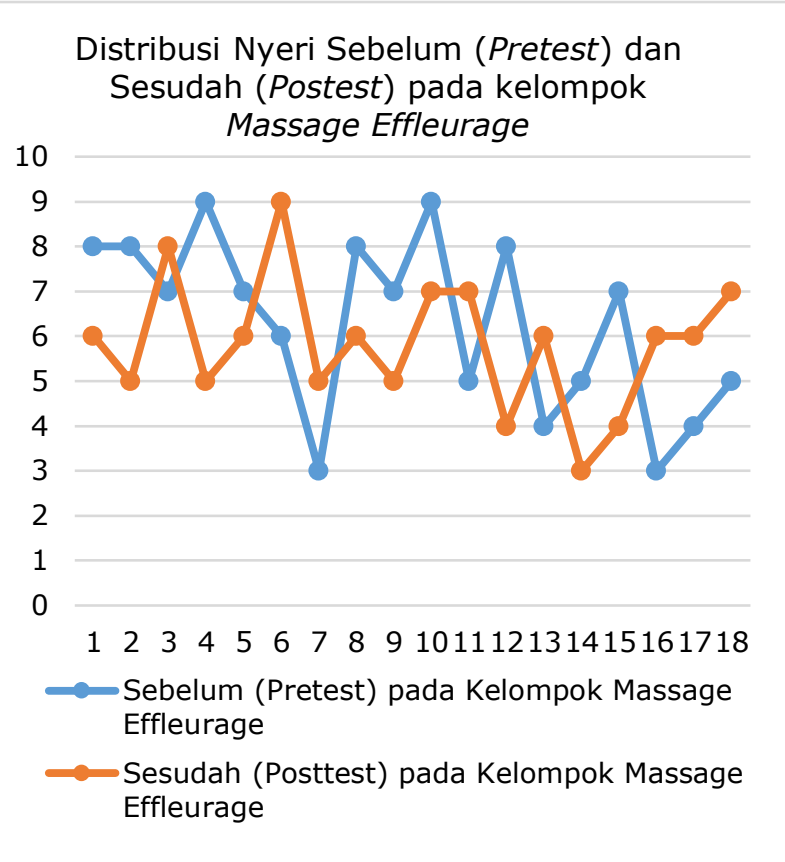

b. Hasil Analisis Sebelum (Pretest) Dan Sesudah (Posttest) Pada Kelompok Massage Effleurage

Grafik 2. Distribusi Frekuensi Intensitas Nyeri Persalinan Kala I Fase Aktif pada Kelompok Intervensi Massage Effleurage

Tabel 2. Perbedaan nyeri persalinan pada kelompok terapi Massage Effleurage (sebelum) Pretest dan (sesudah) Postestt

\begin{tabular}{cc} 
Variabel & $\begin{array}{c}95 \% \text { Confidence Interval } \\
\text { of the Difference }\end{array}$ \\
\hline Mean Std Lower Upper p value \\
Deviation
\end{tabular}

\begin{tabular}{llllll}
\hline Terapi Pretest & 1.83 & 2.40 & 0.63 & 3.03 & 0.005
\end{tabular} Massage Posttest

Effleurage

c. Nilai Rata-rata nyeri persalinan sebelum dan sesudah intervensi dan hasil uji Independent Sample T-Test pada kelompok terapi musik religi dan massage effleurage

Tabel 3. Uji Independent Sample T-Test terhadap kelompok Terapi Musi Religi dengan Kelompok Massage Effleurage 


\begin{tabular}{|c|c|c|c|c|c|}
\hline Kelompok & Mean & SD & f & $\mathbf{t}$ & p value \\
\hline \multicolumn{6}{|l|}{ Terapi } \\
\hline Musik & 5.50 & 0.53 & 0.89 & -2.29 & $\begin{array}{ll}9 & 0.02\end{array}$ \\
\hline $\begin{array}{l}\text { Masagge } \\
\text { Effleurage }\end{array}$ & 4.61 & 0.53 & 0.89 & -2.29 & 90.02 \\
\hline
\end{tabular}

Bagan 1. Rata-rata nyeri persalinan sebelum dan sesudah intervensi pada kelompok terapi musik religi dan massage effleurage

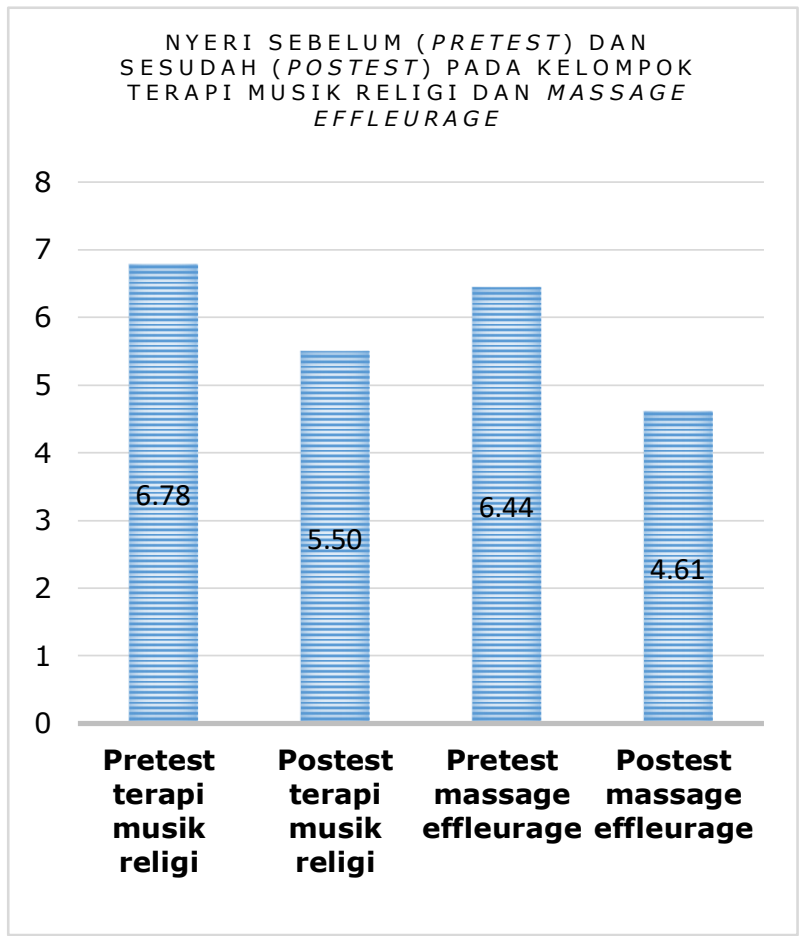

\section{PEMBAHASAN}

a. Hasil Analisis Sebelum (Pretest) Dan Sesudah (Posttest) Pada Kelompok Terapi Musik Religi

Berdasarkan grafik 1 dapat diketahui bahwa distribusi nyeri persalinan pada kelompok terapi musik religi dari 18 responden pada saat sebelum dilakukan intervensi masing-masing mengalami nyeri ringan 1 responden, nyeri sedang 7 responden dan nyeri berat 10 responden, sedangkan setelah diberikan terapi musik religi ada 5 responden yang mengalami nyeri ringan, 10 responden mengalami nyeri sedang dan 3 responden nyeri berat. Sedangkan, berdasarkan tabel 1 dari hasil uji paired t test menunjukkan bahwa nilai $p$ value $0.02<0.05$ yang artinya terdapat perbedaan nyeri persalinan sebelum dan setelah dilakukan pemberian terapi musik religi pada ibu bersalin primigravida.

Terapi musik merupakan suatu terapi yang dapat mengontrol nyeri dan meningkatkan kenyamanan. Untuk memperoleh efek terapi yang maksimal maka, peneliti melakukan intervensi terapi musik selama 30 menit. Menurut The Joanna Briggs Institute tempo dalam terapi musik merupakan faktor penting, pada musik lambat dengan tempo 60-80 denyut per menit dapat memberikan hasil posotif pada relaksasi dan meringankan rasa sakit (Yuliatun., L. 2010).

Hal ini sesuai dengan penelitian Utomo., Armiyati., \& Arif (2015) dari 34 orang yang menjadi responden dan dibagi menjadi dua kelompok, masing-masing kelompok terdiri dari 17 responden, hasil menunjukkan pada kelompok intervensi, rata-rata mengalami penurunan intensitas nyeri 2.29, sedangkan pada kelompok kontrol mengalami penurunan intensitas nyeri 1.24 . Hasil uji statistik yaitu terdapat perbedaan pada kedua kelompok dengan nilai $p=0.000$. maka dapat disimpulkan bahwa musik religi dan nafas dalam efektif digunakan untuk mengurangi nyeri pada pasien post operasi bedah mayor di Rumah Sakit Umum Daerah.

\section{b. Hasil Analisis Sebelum (Pretest) Dan Sesudah (Posttest) Pada Kelompok Massage Effleurage}

Berdasarkan grafik 2 dapat diketahui bahwa distribusi nyeri persalinan pada kelompok massage effleurage dari 18 responden pada saat sebelum dilakukan pengukuran masing-masing mengalami nyeri ringan 1 responden, nyeri sedang 12 responden dan nyeri berat 5 responden, sedangkan setelah dilakukan terapi massage effleurage ada yang mengalami nyeri ringan 2 responden, nyeri sedang 6 responden dan mengalami nyeri berat 10 responden. Sedangkan dari hasil uji paired $t$ test 
menunjukkan bahwa nilai p value 0.005 < 0.05 yang artinya terdapat perbedaan nyeri persalinan sebelum dan sesudah dilakukan massage effleurage pada ibu bersalin.

Rangsangan kulit dengan massage Effleurage dapat menghasilkan implus yang dikirim melalui serabut saraf otak besar yang berada pada permukaan kulit, sehingga otak tidak dapat menerima rangsangan nyeri karena sudah ditutup oleh stimulus kulit dengan metode ini, sehingga persepsi ibu tentang rasa nyeri dapat berubah dan dapat meredakan nyeri, tehnik ini juga dapat mengurangi ketegangan otot dan meningkatkan sirkulasi darah di area yang terasa nyeri (M., Judha., Sudarti \& A., Fauziah. 2012). Hal ini sejalan dengan penelitian Priharyanti Wulandari dan Dwi Nur Hiba (2015) tentang Pengaruh Massage Effleurage terhadap Penurunan Nyeri Persalinan pada ibu Primigravida di ruang bougenville Rsud Tugurejo Semarang dari hasil analisis menunjukkan tingkat nyeri sebelum dilakukan intervensi massage effleurage diperoleh rata-rata 3.78, setelah dilakukan intervensi massage effleurage diperoleh rata-rata 2.96, dengan nilai $p$ value $0.000 \leq 0.05$ disimpulkan Ada pengaruh massage effleurage terhadap tingkat nyeri persalinan (Maryunani., A. 2010).

\section{c. Nilai Rata-rata nyeri persalinan sebelum dan sesudah intervensi dan hasil uji Independent Sample T-Test pada kelompok terapi musik religi dan massage effleurage}

Dari bagan 1 dapat diketahui bahwa nilai rata-rata nyeri persalinan pada kelompok terapi musik religi sebelum dilakukan terapi 6.78 dan setelah dilakukan terapi 5.50 hal ini menunjukan adanya penurunan nyeri sebesar 1.28 , sedangkan pada kelompok massage effleurage ratarata nilai nyeri sebelum terapi 6.44 dan setelah dilakukan terapi 4.61 hal ini juga menunjukkan adanya penurunan nyeri sebesar 1.83 dari hasil analisis data tersebut dapat di simpulkan bahwa kedua metode ini efektif digunakan untuk menurunkan nyeri persalinan. Hal ini sejalan dengan penelitian Wulan., S., Soejoenoes, A., M, S., Hidayat, S., Widyawati., M., \& Gurusinga., R. 2017) tentang The effect of effleurage and abdominal lifting massage in the labor pain dari dari 36 ibu hamil yang dibagi menjadi dua kelompok, yaitu kelompok kontrol dan kelompok intervensi, hasil kombinasi dari massage effleurage dan abdominal lifting yang diterapkan secara bersamaan pada fase aktif (2-3 menit) selama 60 menit, terjadi penurunan nyeri persalinan yang signifikan ( $p \leq 0.05)$. Hasil penelitian ini menunjukkan bahwa massage effleurage dan abdominal lifting merupakan metode yang efektif, sehat, dan layak dalam mengurangi rasa nyeri pada pada saat persalinan.

Dari tabel 3. diketahui bahwa rata-rata nyeri pada kelompok terapi musik religi 5.50 sedangkan rata-rata nyeri pada kelompok massage effleurage 4.61 maka ada perbedaan yang signifikan antara kelompok terapi musik religi dengan kelompok massage effleurage sebesar 0.89, Berdasarkan Tabel 3. Diperoleh hasil bahwa nilai $\mathrm{p}$ velue $0.02<0.05$ yang artinya terdapat perbedaan efektivitas nyeri persalinan kala 1 fase aktif primigravida pada kelompok Kelompok Terapi Musik Religi dengan Kelompok Massage Effleurage. Hal ini sejalan dengan hasil penelitian yang dilakukan oleh Wulan, S., Sitorus, R (2018) tentang pengaruh massage punggung terhadap penurunan nyeri pada ibu post sectio caesarea yang hasilnya menunjukkan bahwa Skala Nyeri Pada ibu Post Operasi Sectio caesarea Sebelum (Pretest) dan Sesudah (Postest) dilakukan Masase di RS Grandmed Lubuk Pakam Kabupaten Deli Serdang memperoleh hasil penurunan skala nyeri. Berdasarkan hasil uji paired t test nilai p 0,001 < 0,05 yang artinya ada pengaruh masase punggung terhadap penurunan skala nyeri pada ibu post operasi Sectio caesarea.

Terapi Musik merupakan elemen yang dapat digunakan untuk meningkatkan, mengembalikan dan mempertahankan, 
kesehatan fisik, mental, emosional, dan spiritual (Utomo., Armiyati., \& Arif. 2015). Terapi musik dalam ilmu kedokteran disebut juga sebagai terapi complementary medicine yang digunakan untuk menurunkan rasa nyeri yaitu terapi musik religi karena terapi ini banyak digunakan sebagai salah satu alternative untuk mempercepat proses penyembuhan, terapi ini juga dapat mendamaikan hati dan dapat menenagkan seseorang yang hatinya sedang merasa cemas, dan gelisah (Karyati \& Hidayah. 2015).

Manfaat Massage effleurage adalah memberikan rasa nyaman pada ibu dan dapat membuat relaksasi, serta merangsang pengeluaran hormone endorphin yang dapat menghilangkan rasa nyeri secara fisiologis (Andari., D., I., Sucipto., E \& Fajaryani., T. 2014) Hal ini di dukung oleh teori Melzack dan Wall tentang Gate Control Teory dimana dengan melakukan massage effleurage dapat menghambat nyeri kontraksi uterus karena serabut A delta akan menutup gerbang sehingga corteks serebri tidak menerima pesan nyeri yang sudah di blokir oleh stimulus massase sehingga persepsi nyeri dapat berubah. Massage effleurage tidak hanya untuk mengendalikan nyeri kontraksi pada ibu bersalin, tetapi dapat dilakukan untuk berbagai nyeri yang ditimbulkan dari rangsangan lain (Priyadarsini S., S., Arangi., S, Patra., T, \& Swain., S. 2014).

Hal ini sejalan dengan penelitian Yanti dan Tazkiyah (2014) tentang pengaruh massage terhadap pengurangan nyeri pada persalinan kala I fase aktif, berdasarkan hasil uji $t$-test diperoleh bahwa ada pengaruh yang signifikan sebelum diberikan massage effleurage dan sesudah diberikan massage effleurage dengan nilai ( $\mathrm{t}$ hitung $=$ $2.931>t$ tabel $=2.042)$ dan $(p$ value 0.006 $<0.05$ ).

Pemberian terapi musik religi dan massage effleurage efektif digunakan untuk mengurangi intensitas nyeri persalinan kala I fase aktif pada primigravida, meskipun dari hasil yang diperoleh menunjukkan bahwa ada responden yang tidak memiliki pengaruh terhadap pengurangan nyeri sesudah dilakukan intervensi, hal ini dikarenakan faktor persepsi atau toleransi terhadap nyeri yang berbeda. Ibu dalam keadaan emosi menghadapi nyeri dan tidak percaya bahwa mereka mempunyai kontrol atau kendali terhadap nyeri, akan dapat meningkatkan kecemasan dan ketakutan yang kemudian menyebabkan ibu stress dan tegang selama datang kontraksi, hal ini yang dapat menyebabkan gagalnya pemberian terapi tersebut.

\section{KESIMPULAN}

Berdasarkan pada analisis hasil dan pembahasan maka disimpulkan bahwa Ada perbedaan yang bermakna antara sebelum (pretest) dan sesudah (posttest) diberikan terapi musik religi dan massage effleurage dengan nilai $\mathrm{p}$ value 0.02 . Kedua metode ini efektif digunakan untuk menurunkan nyeri pada saat proses persalinan, disarankan kepada ibu bersalin atau keluarga untuk dapat menerapkan kedua metode ini.

\section{UCAPAN TERIMA KASIH}

Terima kasih kepada Kementerian Riset, Teknologi, Dan Pendidikan Tinggi (Kemenristekdikti) atas pemberian hibah atau dana bantuan untuk melakukan penelitian di RSGM Lubuk Pakam. Dengan adanya bantuan ini, penelitian dapat berlangsung dengan baik semoga hasil penelitian ini dapat bermanfaat untuk masyarakat khususnya ibu bersalin serta dapat diterapan pada saat ibu bersalin

\section{DAFTAR PUSTAKA}

Andari., D., I., Sucipto., E \& Fajaryani., T. (2014). Perbedaan Tingkat Nyeri Persalinan pada Ibu Bersalin Normal Kala I Primigravida dan Multigravida. Jurnal Keperawatan Tegal Vol.6 No.2,.Ejournal.poltektegal.ac.id. 
Dahlan., S., M. (2013). Besar sampel dan Cara Pengambilan Sampel. Jakarta : Salemba Medika.

Hastono., P., S. (2011). Analisis Data. Jakarta: Fakultas Kesehatan Masyarakat Universitas Indonesia.

Karyati \& Hidayah. (2015). aplikasi terapi musik religi sebagai upaya menurunkan skala nyeri Kab. Kudus. The 2nd University

Research Coloquium ISSN 24079189.

M., Judha., Sudarti \& A., Fauziah. (2012). Teori Pengukuran Nyeri \& Nyeri Persalinan. Yogyakarta : Nuha Medika.

Maryunani., A. (2010). Nyeri Dalam Persalinan "Tehnik dan Cara Penanggulangan". Jakarta : Trans Info Media.

Priyadarsini S., S., Arangi., S, Patra., T, \& Swain., S. (2014). A Study to Assess The Effectiveness of Effleurange to Reduce Labor Pain During 1 Stage of Labor Among Primigravida Women in A Selected Hospital, Bhubaneswar. International Journal of Science Vol 4. Issue 11.

Utomo., Armiyati., \& Arif. (2015). Efektifitas Antara Terapi Musik Religi Dan Slow Deep Breathing Relaxation Dengan Slow Deep Breathing Relaxation Terhadap Intensitas Nyeri Pada Pasien Post Operasi Bedah Mayor Di Rsud Ungaran. Jurnal IImu Keperawatan dan Kebidanan (JIKK), Vol 4, No 1. ISSN: 22526854.

Wulan, S., Soejoenoes, A., Wahyuni, S, M., Thaufik, S, Hidayat., Nurul, M, Widyawati., \& Gurusinga, R. (2018). The effect of effleurage and abdominal lifting massage in the labor pain. Medicine Science International Medical Journal. https://doi.org/10.5455/medscience .2017.06.8670

Wulan, S., \& Gurusinga, R. (2018). february $2018 \mathrm{vol} 3$ no 5 PERBEDAAN NYERI SEBELUM DAN SESUDAH DILAKUKAN TEKNIK RELAKSASI PADA PASIEN SECTIO CAESAREA DI RUMAH SAKIT GRAND MEDLUBUK PAKAM. JURNAL KEBIDANAN HARAPAN IBU PEKALONGAN, 3(5). Retrieved from https://akbidhipekalongan.ac.id/ejournal/index.php/akbidhip/article/vi ew/32

Wulan, S., \& Sitorus, R. (2018). PENGARUH MASSAGE PUNGGUNG TERHADAP PENURUNAN NYERI PADA IBU POST SECTIO CAESAREA. Jurnal Penelitian Kebidanan \& Kespro, 1(1), 27-30. Retrieved from http://ejournal.delihusada.ac.id/index.ph p/JPK2R/article/view/67

Wulandari., P., \& Nur., Hiba., D. (2015). Pengaruh Massage Effleurage Terhadap Pengurangan Tingkat Nyeri Persalinan Kala I Fase Aktif pada Primigravida di Ruang Bougenville RSUD Tugurejo Semarang. Jurnal Keperawatan Maternitas. Vol 3. No 1; 59-67.

Yanti \& Tazkiyah., I. (2014). Pengaruh Teknik Massage Terhadap Pengurangan Nyeri Persalinan Kala I Fase Aktif. Jurnal Kebidanan, Vol. VI, No.01; 59-62.

Yuliatun., L, (2010). Penanganan Nyeri Persalinan dengan Metode Nonfarmakologi. Malang: 